\title{
Investigating Impact of Analysis \\ Matrix Summarization Technique on \\ Iranian University Students' Reading \\ Comprehension Enhancement*
}

Investigación del impacto de la técnica de resumen de matriz de análisis en la mejora de la comprensión de lectura de estudiantes universitarios iranies

Investigação do impacto da técnica de resumo da matriz de análise na melhoria da compreensão da leitura de estudantes universitários iranianos

Samaneh Bahrami

https://orcid.org/0000-0002-9433-7370

Islamic Azad University of Tonekabon, Tonekabon, Iran samaneh.bahrami@gmail.com

Ramin Rahimy

https://orcid.org/0000-0002-0859-7812 Islamic Azad University of Tonekabon, Iran rahimy49@yahoo.com

This paper is derived from the Doctoral dissertation, "A Study of the Impact of Analysis Matrix vs. Backward Summary Technique on English Reading Comprehension Enhancement: A Replication of Wormeli's (2005) Model among Iranian Nursing and Microbiology Candidates at B.S. Level", presented to the Islamic Azad University of Tonekabon. Available at: www.ris.iau.ac.ir

Received: 27/01/2020

Accepted by peers: $23 / 04 / 2020$
Sent to peer review: $28 / 01 / 2020$

Approved: 03/05/2020

DOI: $10.5294 /$ laclil.2020.13.2.3

To reference this article (APA) / Para citar este artículo (APA) / Para citar este artigo (APA) Bahrami, S., \& Rahimy, R. (2020). Investigating impact of analysis matrix summarization technique on Iranian university students' reading comprehension enhancement. Latin American Journal of Content \& Language Integrated Learning, 13(2), 191-214. https://doi. org/10.5294/laclil.2020.13.2.3 
ABSTRACT. The present study was an attempt to investigate the effect of the analysis matrix, a type of graphic organizer, as a language improvement supportive attempt on fostering reading comprehension in an EFL academic context. The main question this study tried to answer was whether using this technique might enhance reading comprehension abilities among Iranian non-English majors. To achieve this goal, 120 nursing and microbiology majors were randomly selected from a population of the non-English majors enrolled for the Academic English course. They were divided into four groups of 30 and were randomly assigned to two experimental groups and two control groups. A pre-test of reading comprehension was administered to all groups. Then, they were taught passages to read for eight sessions with different methods; the experimental groups received a treatment of analysis matrix technique instruction while the control groups were taught with the traditional method, including no summarization instruction. A post-test of reading comprehension was finally administered to all groups. The data were analyzed using one-way analysis of covariance (ANCOVA) to control the effects of the pre-test on the outcomes. The results indicated a statistically significant difference due to pedagogical intervention; the two experimental groups outperformed on the post-test after being treated with analysis matrix technique for eight sessions.

Keywords (Source: Unesco Thesaurus): Content-based academic reading; non-English majors; summarization; graphic organizers; analysis matrix summarization technique; reading habit; reading promotion.

RESUMEN. El presente estudio fue un intento de investigar el efecto de la matriz de análisis, un tipo de organizador gráfico, como un intento de apoyo a la mejora del lenguaje para fomentar la comprensión de lectura en un contexto académico de inglés como lengua extranjera. La pregunta principal que este estudio buscaba responder fue si el uso de esta técnica podría mejorar las habilidades de comprensión de lectura entre los estudiantes iraníes que no eran de la Licenciatura en inglés. Para alcanzar este objetivo, se seleccionaron 120 estudiantes de enfermería y microbiología al azar de una población de estudiantes que no hacían parte de la Licenciatura en inglés y que estaban inscritos en el curso de Inglés Académico. Se dividieron en cuatro grupos de 30 y se asignaron aleatoriamente a dos grupos experimentales y dos grupos de control. A todos los grupos se les administró una prueba previa de comprensión lectora. A continuación, se les enseñaron pasajes para leer durante ocho sesiones con diferentes métodos; los grupos experimentales recibieron un tratamiento de instrucción de técnica de matriz de análisis mientras que los grupos de control recibieron instrucción con el método tradicional, incluyendo sin instrucción de resumen. Finalmente, se administró una prueba posterior de comprensión de lectura a todos los grupos. Los datos se analizaron mediante análisis de covarianza unidireccional (ANCOVA) para controlar los efectos de la prueba previa en los resultados. Los resultados indicaron una diferencia estadísticamente significativa debido a la intervención pedagógica; los dos grupos experimentales obtuvieron mejores resultados en la prueba posterior después de que se aplicara la técnica de matriz de análisis durante ocho sesiones.

Palabras clave (Fuente: tesauro de la Unesco): Lectura académica basada en el contenido; estudiantes de programas diferentes a la Licenciatura en inglés; organizadores gráficos; técnica de resumen de matriz de análisis; hábito de lectura; promoción de la lectura.

RESUMO. O presente estudo foi uma tentativa de investigar o efeito da matriz de análise, uma espécie de organizador gráfico, como uma tentativa de apoiar o aprimoramento da linguagem para promover a compreensão de leitura em um contexto acadêmico de inglês como língua estrangeira. A principal questão que este estudo buscou responder foi se o uso dessa técnica poderia melhorar as habilidades de compreensão de leitura entre estudantes iranianos de programas diferentes do bacharelado em inglês. Para atingir esse objetivo, 120 alunos de enfermagem e microbiologia foram selecionados aleatoriamente em uma população de alunos de programas diferentes do bacharelado em inglês e que estavam matriculados no curso de Inglês Acadêmico. Os estudantes foram divididos em quatro grupos de 30 e distribuídos aleatoriamente em dois grupos experimentais e dois grupos de controle. Todos os grupos foram submetidos a um teste prévio de compreensão de leitura. Em seguida, foram mostradas a eles passagens para ler por oito sessões com métodos diferentes; os grupos experimentais receberam instruções sobre a técnica de matriz de análise, enquanto os grupos de controle receberam instruções com o método tradicional, sem incluir nenhuma instrução de resumo. Finalmente, um pós-teste de compreensão de leitura foi administrado a todos os grupos. Os dados foram analisados usando uma análise de covariância unilateral (ANCOVA) para controlar os efeitos do pré-teste nos resultados. Os resultados indicaram uma diferença estatisticamente significante devido à intervenção pedagógica; os dois grupos experimentais tiveram melhor desempenho no pós-teste após a aplicação da técnica da matriz de análise em oito sessões.

Palavras-chave (Fonte: tesauro da Unesco): Leitura acadêmica baseada em conteúdo; alunos de programas diferentes do bacharelado em inglês; organizadores gráficos; técnica de resumo de matriz de análise; hábito de leitura; promoção da leitura. 


\section{Introduction}

In the globalization era, reading comprehension skill has turned into an urgent need for a large number of people who rarely speak English for their daily communication throughout the globe (Hodaeian \& Biria, 2015; Zafarani \& Kabgani, 2014). Furthermore, it has gained a unique significance in an EFL academic context, for it is the fastest means of raising students' educational level (Lin \& Chern, 2014). In fact, reading is the most important language skill for university students because, in most content or English for specific purpose courses, they are just required to read long technical passages together with comprehension questions, instructions for exercises and so forth (Anderson, 1999; Lin \& Chern, 2014; Zafarani \& Kabgani, 2014). Reading can be an end in itself, since it is a major source of comprehensible input and "a key to linguistic growth" (Chaury, 2015, p. 1). Although there is clear evidence that strategy training promotes reading comprehension (National Reading Panel, 2000), no study has separately analyzed effects of various strategies in detail, and it is not clear at all that some or only one of the taught strategies can really be effective in improving students' reading comprehension.

As the students go on with higher education, requirements for reading with accuracy and proficiency are increasing steadily, and the subjects are becoming more challenging and complicated (Lin \& Chern, 2014). Whether it is the need to learn something new, increase knowledge or search for information, they should be able to read with comprehension (Grabe, 2009; Grabe \& Stoller, 2011). Furthermore, the reading tasks encountered by university students are totally different from the previous stages of their education. As Lin and Chern (2014) mention, "English is no longer merely the subject of study. Instead of focusing on language details used in the text, the attention is now on the information of content" (p. 152). Unfortunately, due to lack of sufficient exposure to English texts, and the frequent use of traditional methods, such as the grammar-translation method by the majority of the teachers in lower grades, many Iranian university students are not fully prepared for demanding academic reading tasks (Mall-Amiri \& Sarlak, 2010; Zahedi \& Tabatabaei, 2015). 
Strategic reading instruction is still undeveloped and not commonly practiced among many Iranian high school teachers (Tarshaei \& Karbalaei, 2015). The dominant traditional method still advocates the teacher-centered, book-centered, grammar-translation method and puts more emphasis on rote learning and memorization rather than other practicable skills (Mohammad-Hosseinpur, 2015). Moreover, the instruction and use of summarizing techniques in Iranian high schools is not strictly emphasized. The outcome, in the words of Zafarani and Kabgani (2014), is the "inability of [most Iranian university] students to develop some necessary skills and strategies required in reading comprehension" (p. 1960).

At college, students are required to read long challenging texts. Far from being reader-friendly, such texts are commonly replete with lots of complexities and technical terms. They are supposed to read and comprehend these texts on their own, which is a great challenge beyond the grasp of many Iranian university students because it requires reading between the lines and thinking critically (Mall-Amiri \& Sarlak, 2010; Mohammad-Hosseinpur, 2015; Zafarani \& Kabgani, 2014). Moreover, the ability to summarize what they read seems to be an essential skill in academic contexts, considering the length of the passages usually read in higher-education level. In these contexts, students often need to summarize information from lectures, journals, textbooks, and other sources in order to do the assignments related to their own fields of study (Pakzadian \& Eslami-Rasekh, 2012; Tarshaei \& Karbalaei, 2015). However, most Iranian university students have difficulty in differentiating main ideas from details and redundant information and restating what they read in their own words.

Unfortunately, many teachers just take it for granted that their students know how to summarize after years of studying English (Tarshaei \& Karbalaei, 2015). The truth is that summarization is a challenging and complicated task that needs instruction and lots of practice. In fact, many students have difficulties in writing a good summary even in their L1. For many Iranian university students, summarization just means copying the exact sentences from the original text. Some even consider it a futile effort, as the original text is already at hand. (Mohammad-Hosseinpur, 2015; Zahedi \& Tabatabaei, 2015; Zafarani \& Kabgani, 2014). The present study was conducted to change these false 
beliefs. Analysis matrix summarization technique was instructed with the aim of facilitating the reading comprehension skills of non-English major university students in an academic foreign language context.

It is also necessary to explain about the Academic English Course in Iranian universities. It is a preliminary to English for specific purposes (ESP) courses; all university students, regardless of their majors, must participate in this compulsory course. The course focuses on teaching non-core academic content through English and improving reading abilities. The texts are not technical or limited to any specific field of study; on the contrary, short, simple passages with different topics are used with the aim of encouraging the students to build up vocabulary, become familiar with comprehension strategies and learn not to rely on mental translation as the only way for comprehending English texts. The diversity of topics helps them to gain information and add to their background knowledge through reading in English. In sum, the aim of this course is to prepare Iranian university students to continue with the more challenging, technical, field-related passages they are going to read in ESP courses. Similarly, the aim of the current study was to foster non-English major students' reading comprehension skills and preparing them for more challenging academic reading tasks ahead. That's why this preliminary course was chosen for conducting the current study. The selected course book was written by a group of experienced Iranian university professors for familiarizing non-English majors with expository English texts. Eight lessons from the book were used for this study.

\section{Theoretical background}

There has been growing recognition that reading is the most important language skill required for achieving academic success in a foreign language context (Lin \& Chern, 2014). Undoubtedly, there is more to comprehension than just learning the new words and translating the passage. Reading comprehension is a complex skill that can be aided by cognitive strategies such as summarizing. Hirvela (2016) states that, since "the process of creating a condensed version of a source material 
requires close reading of the source... [it] enriches students' comprehension skills" (p. 61). Kamil (2004) believes summarization boosts comprehension by encouraging the learners to "focus on the main point instead of the unnecessary details and exclude the redundant or irrelevant information" (p. 120). Therefore, if students are able to summarize well, they improve their reading comprehension abilities (Baleghizedeh \& Babapur, 2011; Naseri et al., 2013; Palmer, 2003; Sotiriou, 2002).

Although asking students to summarize what they read is part of the academic core curriculum and is considered a common practice to check comprehension in many academic English, ESP, and content courses, adequate instruction on how to write a good summary is not usually given to students (Baleghizadeh \& Babapur, 2011; Mohammad-Hosseinpur, 2015; Pakzadian \& Eslami-Rasekh, 2012). Teachers should not assume that students who are good readers in their L1 are able to easily apply all the necessary strategies when reading in English as an FL. Instead of assuming that their students are competent at reading academic English texts and summarizing what they read, instructors should help them to develop the skills and mastery required to fulfil these tasks on their own since reading comprehension and summarizing skills form the heart of academic literacy (Hodaeian \& Biria, 2015; Mall-Amiri \& Sarlak, 2010; Mohammad-Hosseinpur, 2015; Naseri, et al., 2013; Tarshaei \& Karbalaei, 2015).

Graphic illustrations provide a means of teaching students how to recognize text structures, so "students are expected to comprehend texts better when shown visually how information in the text is organized" (Jiang \& Grabe, 2007, p. 39). Ellis and Howard (2005) define graphic organizers (GOs) as devices in the form of maps, charts, tables, graphs and diagrams for displaying information that "serve as visual cues designed to facilitate communication and/or understanding of information by showing how essential information about a topic is organized" (p. 1). GOs are often used to assist readers with organizing their ideas with graphic representations of what they read (Harris \& Hodges, 1995). As Praveen and Premalatha (2013) state, they "need not be complicated; rather they need to be simple and assist the students in understanding a concept clearly" (p. 161). They have been considered as both cognitive and language tools. As cognitive tools, they can organize and sort information and ideas (Chang et al., 2002; Chmielewski 
\& Dansereau, 1998; McKnight, 2010; Parker, 2007; Pearson \& Denner, 1989). As O'Donnell and Wood (2004) point out, "one of the major principles of comprehension is that organizing and classifying new information facilitates understanding and remembering" (p. 190). Readers cannot recall everything they read, so it is essential to distinguish the most important ideas (National Reading Panel, 2000).

In fact, information recall is an issue closely related to reading comprehension. As language tools, GOs not only emphasize semantic relationships but also offer opportunities for the learners to exercise the use of language (Pearson \& Denner, 1989; Salehi et al., 2013).

Analysis matrix is a sort of GO that was first investigated by Schwartz and Fattale (1972) and later advanced by Kiewra et al. (1999). It is often used with expository texts. In fact, by illustrating the organization and structure of the text, it fosters learning (Chang et al., 2002; Manoli \& Papadopoulou, 2012; Praveen \& Premalatha, 2013; Wormeli, 2005). Graney (1992) describes it as a sort of input table used for illustrating key concepts, comparing and contrasting. Wormeli (2005) regards it as a flexible summarizing tool that can "provide a template for creating an outline" (p. 46) of the passage and be used in all stages of reading as a form of visual summary. In order to design an analysis matrix, it is necessary that learners identify both the main ideas and relationships they wish to display (Graney, 1992; Wormeli, 2005).

The specific benefit of analysis matrices, according to Kiewra et al. (1999) is illustration of relations and key concepts in a two-dimensional frame, which facilitates the information extraction. In addition, they can "convert linear textual statements into nonlinear graphic presentations" (Chang et al., 2002, p. 6). These features make them ideal for depicting comparisons and coordinating relations among key concepts, specifically in expository texts, which are frequently used in academic contexts. Furthermore, as Wallace et al. (2007) point out, they help students to form "a preliminary structure for organizing their thoughts" (p. 51). Thus, students can take an active role in learning by focusing on the main points and summarizing the passages with the aim of fostering comprehension. This can pave the way to become more "critical, analytical, independent, and strategic readers" (Manoli \& Papadopoulou, 2012, p. 348) who eagerly take responsibility for learning, share ideas with their peers and make informative decisions. Fisher (2001) 
considers them as effective instructional tools to foster reading comprehension since they assist students at different levels and with different language proficiency to explore and display the relationships between ideas.

Matrices can also be used to summarize texts and demonstrate key concepts in an organized and related way, reducing the cognitive load and comprehension barriers (National Reading Panel, 2000). They can be easily adapted to meet the demands of diverse groups of learners in a variety of educational contexts. Teachers should use them according to the age level, needs and interests of their students to facilitate meaningful learning and avoid rote learning or dissatisfaction. The ultimate goal of instructors should be to utilize them properly to organize the material in a way that enables their students to interact with the text and make connection between what they learn and their background knowledge (Praveen \& Premalatha, 2013; Wallace et al., 2007).

To sum up, being adaptable and having numerous functions turn matrices into an ideal option for instructors "to meet the needs of a wide range of students" (Manoli \& Papadopoulou, 2012, p. 48). They "can be used to facilitate learners' comprehension process before, during, and after reading" (Manoli \& Papadopoulou, 2012, p. 48). In their review, Manoli and Papadopoulou (2012) state that "research has shown consistent effects favoring the use of matrix to locate relations and answers to questions and boost relational learning" (p. 350). In order to gain utmost results, analysis matrices should be considered as language improvement supportive tools within the larger context of insightful pedagogy.

Based on the already-mentioned points, and regarding the importance of organizing a framework for identifying and organizing the main and supporting ideas, extracting key concepts from the passage and summarizing the read materials to facilitate reading comprehension and retention, the current study aimed to answer the following questions:

$\mathrm{Q}_{1}$ : Does analysis matrix as a graphic organizer enhance English reading comprehension among Iranian microbiology candidates at Bachelor of Science (B.S.) level?

$\mathrm{Q}_{2}$ : Does analysis matrix as a graphic organizer enhance English reading comprehension among Iranian nursing candidates at B.S. level? 


\section{Method}

\section{Participants}

A pool of 120 first-year, non-English majors, including 60 nursing and 60 microbiology major undergraduate students of the Islamic Azad University of Babol, in the North of Iran, participated in this study. Since the current research was conducted as a Ph.D. dissertation project, the number of participants was decided by the thesis advisor.

The participants were native Persian speakers, and their age ranged from 18 to 24 years. They were selected for this study randomly from the whole population of non-English major students who enrolled in the compulsory Academic English course at the time of the experiment. They were divided into four intact classes (random selection of students was not possible for the researchers due to university rules, and the participants were limited to the students who enrolled for the course at the time of the study) and were randomly assigned to two experimental groups and two control groups: nursing experimental, microbiology experimental, nursing control, and microbiology control groups. Each class contained 30 students. Due to administrative and time restrictions, using intact classes was the only available option for the researchers, who were academic staff members of the Islamic Azad University. It was decided that all the classes were to be taught by one of the researchers (the Ph.D. candidate) under the supervision of her thesis advisor (the other researcher) for the sake of the internal validity of the research.

All the participants were high school graduates currently pursuing a B.S. degree in nursing and microbiology. They had the experience of studying English with the grammar-translation method in high school for at least 4 years. They were all struggling learners who had difficulty comprehending academic texts in English.

\section{Material}

The reading materials were taken from the second edition of Reading for General English (2010), a course book for university students developed by SAMT (a Farsi acronym), which is the main organization for 
researching, composing, and publishing academic textbooks in the field of humanities in Iran. The titles of the units are as follows:

Unit 1. The Age of the Dinosaur

Unit 2. A World below Trees

Unit 3. Showtime

Unit 4. Life in the Sea

Unit 5. Rainbows

Unit 6. How Does Your Skin Grow?

Unit 7. From Tadpole to Frogs

Unit 8. Treasures from the Deep

This book was selected as the main course book because it included a mapping activity exercise at the end of each unit to summarize what had been read. It consisted of an input table asking students to extract the relevant information from the passage. In this study, analysis matrix referred to these visual outlines of the passages based on the mapping activity exercise of the course book. The students were supposed to complete them by extracting the relevant information from the text and writing them under the proper columns. For instance, for the first unit, which was about dinosaurs, they were supposed to extract the related information about the appearance, size, food, the study of fossils, manner of reproduction, and the cause of the extinction of the dinosaurs, and write the relevant information under the proper columns. Moreover, using short expository texts made this book a good choice to practice with the struggling students who had no previous instruction on summarization, limited exposure to English texts, mostly through high-school English books, and got used to traditional methods. It is essential for university students, especially non-English majors, to be familiar with expository texts, since most academic reading tasks deal with comprehending such passages.

\section{Instrument}

In this study, English reading comprehension was measured by a researcher-made multiple-choice test to check whether students were able to grasp the main ideas and supporting details of a text, figure out 
the purpose of the writer, and infer from the text-based information. The test included four passages from the textbook, and each passage was followed by five multiple choice questions. In order to determine the entry behavior of the individuals in the control and experimental groups, a reading comprehension test was administered as the pretest. After the intervention, the same reading comprehension was given as the post-test to identify students' gain in terms of the treatment employed. The validity of the tests was specified based on specialist opinions, and the reliability was measured by piloting the tests on forty students identical to the target samples. A reliability analysis was carried out on the reading comprehension test. The Cornbach alpha was calculated by the SPSS program. The reliability of the test was 0.86 , which was considered acceptable according to the criterion of 0.70 , as suggested by Robson (1993).

\section{Procedure}

Prior to the beginning of the experiment, the researcher had a meeting with each of the four classes separately and informed them of the research project. Academic English was a compulsory course, and the experiment was intended to be conducted during regular weekly classes; therefore, taking part in the experiment included no extra time or extra-curricular responsibilities for the participants. Moreover, they were all assured that their identities would be kept confidential, and the test scores would only be used for evaluating the results of the experiment. The students were struggling learners, but they were eager to improve their reading comprehension abilities; consequently, they eagerly agreed to cooperate.

The study had a quasi-experimental design; intact classes were randomly assigned to experimental and control groups (Ary et al., 2013) and included three phases of pre-testing, pedagogical intervention, and post-testing. Analysis matrix was used as a summarizing technique to visualize the relationship between key concepts and supporting details of the passage. Before the pedagogical intervention, the researcher introduced the idea of using analysis matrices to summarize and visualize the key points of the text. Then, she demonstrated how to apply this technique to self-monitor reading comprehension 
by using some example paragraphs and modelling the strategy for the students. She applied the thinking aloud technique to explain explicitly how to use analysis matrix to summarize what she had read. She also used the worksheets based on the mapping activity of the course book to familiarize students with the technique of designing the visualized outline of what they were about to read. She urged the students to use this technique to extract information from the passage and self-monitor their own comprehension by building a quick outline or a visual summary of the passage. Like doing a puzzle, the parts would be put together to form the big picture. After practicing with some paragraphs as examples and showing the students what to do, a selected text from the course book was introduced to the class. First, the unknown key words were briefly explained and reviewed with the students. Next, each paragraph was read aloud by a volunteer. The students were asked to identify the text elements, such as the topic sentence, main idea, and supporting details of each paragraph. If they had any problems with confusing words, phrases or sentences, the teacher clarified the difficult points. Then, the teacher asked them to reread the passage and complete the visual outline by extracting the relevant information from the passage. The students could work on their worksheets either alone or in pairs, and the teacher walked around providing them with the support each time they had any questions or difficulties in completing the task. The time allotted to reread the text and complete the matrix worksheet was twenty minutes. The teacher told the students they must try their best to complete the task within the time limit. The purpose of giving the students the proposed time limit was to avoid the possibility that the students' reading comprehension was affected by the time designated to complete the visual outline.

After completing the text map, the students were asked to write a brief summary of what they had read by using the outline, rereading the original passage, focusing on the main ideas, and ignoring unimportant or redundant parts. They were also encouraged to avoid copying the exact words or sentences used in the original text. The time allotted to write the summaries was fifteen minutes. During this follow-up stage of writing activity, the teacher walked around and provided the students with help if they had any problems regarding wording and sentence formation. The summaries were collected and read by 
the teacher. The papers were returned to the students the following session, together with the written teacher comments and feedback. Fifteen minutes were allotted to read some of the summaries written the previous session in class. With the aim of improving learners' reading comprehension and avoiding their dissatisfaction by low scores, teacher's feedback, instead of marks, was given for the written summaries. The teacher commented on how the students had understood the text, how they had used selection, abstraction, cohesion, and addition, and gave suggestions on how to improve the summary. In fact, teacher feedback acted as a sort of dialogue between the teacher and the students in regard to their readings in class. For the homework, the students were told to keep a journal and write about what they learned in the passage. They were also told to reread the text and make a list of all the new words they learned in the passage. They were asked to write down the parts of speech and meanings of these words, trying to use English synonyms, antonyms or explanation instead of equivalents in Farsi. The intervention lasted eight sessions, and with each session the students gained more responsibility in using the technique to outline and summarize what they read.

Finally, for the control groups, the traditional method of reading a passage and doing comprehension check exercises, such as true or false, multiple choice exercises, and answering the questions by copying the answers from the passage (without paraphrasing sentences), were used. For both the experimental and control groups, the instructional materials and learning content were the same, except that the control groups were not exposed to mapping activities and summarization instruction. They were taught by the familiar traditional teacher-centered reading approach in which the teacher directed the instruction, initiated the questions, and the students generated responses by copying the answers from the texts. This traditional approach focused on vocabulary teaching by emphasizing on Farsi equivalents, analysis of grammatical structures of the texts, and detailed translation of the English text. In fact, this is the common practice in public high schools, so the control group members were pleased to follow the routine and did not have any problems with continuing their studies with the familiar traditional method. 


\section{Results}

The obtained data were analyzed by calculating one-way Analysis of Covariance (ANCOVA) with the aim of controlling the effects of pre-testing on the outcomes.

An analysis of covariance was conducted on each pair of experimental and control groups' scores, taking the pre-test as the covariate, and the post-test as the dependent variable, with the aim of investigating if the improvements in the post-test performance were due to the instructional intervention. All the three assumptions of ANCOVA that are normality of the data distribution, homogeneity of the variances and a correlation between the covariate and the dependent variable were checked and met before running the ANCOVA.

Table 1 illustrates the results of ANCOVA for the two microbiology experimental and control groups.

Table 1. ANCOVA results for the microbiology groups

\begin{tabular}{|l|c|c|c|c|c|c|}
\hline \multicolumn{1}{|c|}{ Source } & $\begin{array}{c}\text { Type III } \\
\text { Sum of } \\
\text { Squares }\end{array}$ & df & $\begin{array}{c}\text { Mean } \\
\text { Square }\end{array}$ & $\mathbf{F}$ & Sig. & $\begin{array}{c}\text { Partial } \\
\text { Eta- } \\
\text { Squared }\end{array}$ \\
\hline $\begin{array}{l}\text { Corrected } \\
\text { Model }\end{array}$ & $578.713^{\mathrm{a}}$ & 2 & 289.357 & 147.763 & .000 & .838 \\
\hline Intercept & 224.602 & 1 & 224.602 & 114.696 & .000 & .668 \\
\hline pre & 38.713 & 1 & 38.713 & 19.769 & .000 & .258 \\
\hline group & 530.062 & 1 & 530.062 & 270.682 & .000 & .826 \\
\hline Error & 111.620 & 57 & 1.958 & & & \\
\hline Total & 9572.000 & 60 & & & & \\
\hline Corrected Total & 690.333 & 59 & & & & \\
\hline
\end{tabular}

a. $\mathrm{R}$-squared $=.838$ (Adjusted R-squared $=.833$ )

Source: Own elaboration.

According to Table 1, the $F$ value for the two groups equals 270.682, and the $p$ value is less than 0.05 , so the two groups are significantly different in terms of their performance on the post-test. Moreover, the partial effect size, which gives us an indication of the magnitude of the effect on the population at large is 0.828 , which is quite high. 
Regarding the actual effect of the covariate, that is the pre-test, the F value is 38.713 .

Since the $p$ value is less than 0.05 , the covariate has a significant effect on the outcome.

Consequently, it is a variable that should have been included as the covariate because it was going to have a negative effect on the effectiveness of the pedagogical intervention. It appears that the experimental group outperformed the control one in the post-test and gained better scores on their reading comprehension final exam. In sum, it can be concluded that the instructional intervention, which is using analysis matrix, has a statistically significant effect on reading comprehension enhancement of the microbiology majors while controlling for the effect of the pre-test.

The same procedures were followed with the two nursing groups, as well. Table 2 shows the results for the nursing majors.

Table 2. ANCOVA results for the nursing groups

\begin{tabular}{|l|c|c|c|c|c|c|}
\hline \multicolumn{1}{|c|}{ Source } & $\begin{array}{c}\text { Type III Sum } \\
\text { of Squares }\end{array}$ & df & $\begin{array}{c}\text { Mean } \\
\text { Square }\end{array}$ & F & Sig. & $\begin{array}{c}\text { Partial Eta- } \\
\text { Squared }\end{array}$ \\
\hline $\begin{array}{l}\text { Corrected } \\
\text { Model }\end{array}$ & $618.902 a$ & 2 & 309.451 & 123.105 & .000 & .812 \\
\hline Intercept & 319.214 & 1 & 319.214 & 126.989 & .000 & .690 \\
\hline pre & 23.552 & 1 & 23.552 & 9.369 & .003 & .141 \\
\hline group & 517.787 & 1 & 517.787 & 205.985 & .000 & .783 \\
\hline Error & 143.281 & 57 & 2.514 & & & \\
\hline Total & 10465.000 & 60 & & & & \\
\hline Corrected Total & 762.183 & 59 & & & & \\
\hline
\end{tabular}

a. R-squared $=.812$ (Adjusted R-squared $=.805$ )

Source: Own elaboration.

As Table 2 indicates, the $F$ value for the two nursing groups is 205.985, which is statistically significant because the $p$ value is less than 0.05 . Thus, the two groups are different regarding their post-test scores. 
As far as the covariate is concerned, the $F$ value equals 9.369. The $p$ value does not exceed 0.05 , indicating a significant effect on nursing majors. The partial effect size is 0.783 , which is a high effect. The experimental group outperformed on their reading post-test. Consequently, the pedagogical treatment, including analysis matrix instruction, seemed to improve reading comprehension skill of the nursing majors, as well.

Based on the observed results from both the microbiology and nursing experimental groups, it can be claimed that analysis can foster reading comprehension in Iranian non-English majors.

\section{Discussion}

The current study was concerned with determining the effectiveness of explicit practice of the analysis matrix summarization technique as a language improvement supportive attempt on reading comprehension enhancement of Iranian non-English major university students. The control groups only received traditional reading comprehension training, without any summarization instruction, whereas the experimental groups were exposed to analysis matrix technique for summarizing what they had read in class. The first finding of the study was that, compared to the control groups, both experimental groups showed statistically significant progress in reading comprehension from their pre-tests to post-tests. All nursing and microbiology experimental group members showed further improvement compared to control groups, throughout the eight weeks in their ability to respond to reading comprehension questions. Based on the ANCOVA results, the instructional intervention led to reading comprehension enhancement while controlling for the effect of pre-testing. This positive effect on reading comprehension is in line with the previous research in ESL/ EFL contexts (Biria \& Sharifi, 2013; Lee et al., 2005; Praveen \& Premalatha, 2013; Salehi et al., 2013). What the current study may add to this positive picture is the efficiency of using graphic representations as visual outlines and as language improvement supportive attempts to enhance comprehension, retention and summarization of the read 
materials in an academic EFL context, as well. Considering the length of the passages commonly read in the academia, graphic representations can be very useful for university students, especially in an EFL context. They can be viewed as both a teaching strategy for presenting long technical texts and a learning strategy for summarizing the textual information and structure.

The next finding of the study was that visual presentation of the text information helped students to distinguish main ideas from details. When the experiment started, students had frequent problems in this regard. They could not identify main ideas and supporting details and had difficulties with other reading comprehension skills, such as summarizing, making conclusions, making inferences, and identifying author's purpose. After the instruction and constant use of analysis matrix summarization technique, they got a good command of categorization and organization of ideas, which led them to improved comprehension of the read materials. Therefore, it is essential for teachers to apply strategies to enhance students' reading comprehension. In fact, the search for finding appropriate strategies to foster learning should be considered a lifelong quest for instructors.

The mapping activity used in this study as a summarization technique helped the learners in several ways. Firstly, it led to a more purposeful and focused reading of the text. Memory has a limited capacity, so it is not possible to pay attention to all the details of the passage simultaneously, and remember all of them, especially in an EFL context. Breaking the key concepts into meaningful chunks and asking the learners to pick the needed information from the text can lead to meaningful learning and avoid memorization, losing interest, mental translation and frustration. As Wormeli (2005) states, "learning doesn't occur while you are doing the thing itself. Learning comes in the debriefing afterward" (p. 5). Secondly, the activity was congruent with the completion strategy (van Merrienboer, 1990), advocating the use of completion tasks to overcome cognitive overload problems. Thirdly, the summarization technique enhanced comprehension by encouraging the learner to "focus on the main point instead of the unnecessary details and exclude the redundant or irrelevant information" (Kamil, 2004, p. 120). Finally, it facilitated retention by making mental representations of the text. The visually illustrated input can facilitate 
both storing and recalling of the information, which leads to improved comprehension.

Focusing on the main idea, deleting redundant information and distinguishing main ideas from the supporting details are emphasized in both graphic representations and summary writing. In fact, analysis matrix served as a bridge between reading comprehension and summary writing. In order to avoid frustration and overload problems, the students were not required to construct the graphic representations of the texts read by themselves. The gist of each passage was given to them in the form of a simple visual outline. All they needed to do was extract the relevant information from the passage and complete the table. The complete table could display the gist of the text and be easily turned into a brief written summary. From this viewpoint, the findings of the current study are in accordance with the existing research (Grabe \& Zhang, 2013; Hirvela, 2016; Wallace et al., 2007; Zhao \& Hirvela, 2015) that considers reading and writing as two inextricably related modes of language and claims that reading-writing connections may be beneficial in fostering students' reading comprehension, especially in an EFL academic context. Since source-based writing tasks are common in academic contexts, implementing graphic representations as visual summaries should be encouraged as an effective teaching and learning strategy. Undoubtedly, they can be a proper substitution for a wordfor-word oral or mental translation of the text, which is, unfortunately, a common practice in many ESP and academic English courses. They provide the students with visual supports in processing information according to their foreign language knowledge (Hibbard \& Wagner, 2003).

Another finding of this study was encouraging self-monitoring by using visual outlines of the texts; the experimental groups were trained to employ the analysis matrix technique to gain a better understanding of what they had read. They were told not only to use the technique, but also to know when, why, and how to use it. They learned to form mental maps, identify the main idea of each paragraph and distinguish it from the details, summarize their reading by using visual maps, and write about what they had read with the help of the visual outlines. These strategies helped them overcome difficulties by planning and self-monitoring their comprehension, as well as evaluating the outcome of such planning. During the pedagogical intervention, the 
participants in the experimental groups learned to successfully fulfil all the already-mentioned functions. They knew what to do and how to do it before reading, while reading, and after reading. They planned, self-monitored, and self-evaluated all throughout the reading process. In other words, they set the purposes of reading before actually starting to read. Then, in while-reading, they formed mental maps and visual outlines of what they had read, and they could better control their thinking process and awareness to comprehend a passage. They also tried to solve the problems they encountered within while reading. They evaluated their own comprehension and self-regulated their use of the technique. They used the visual outlines to write briefly about what they had read. Moreover, they learned how to implement the technique for their future readings.

The findings also indicated that instructions of techniques and strategies must be done in steps. The instructors should provide the students with appropriate explanations, explicit modeling, and on-going guidance. They should model the process explicitly and step by step. The students should be told about the technique and when, why, and how to implement it. They need both enough time to practice it and consistent encouragement from the instructor. Moreover, instructors should try to increase their students' responsibility by gradually decreasing their prompts and modeling through changing their own role to facilitators. They should also be flexible and attentive to help their students. If the learners have problems, the teachers should provide enough support and guidance to make sure their students become strategic independent readers. In fact, for getting utmost results, strategy instruction should be reinforced through scaffolding. As Chang et al. (2002) put it, "the scaffolding instruction method ha[s] better direct and transferring effects than general teaching methods that do not provide gradual scaffolding [,] support and removal" (p. 20).

Material selection should be taken into careful consideration, as well. It should be based on students' needs, abilities, and interests. Teachers ought to be aware of their students' levels, needs and interests in order to be able to assist them accordingly. Students should be given short passages to read first. Gradually, with enough practice, and after internalizing the instructed technique, they can move on to long ones, motivated to read and learn effectively. 
To sum up the findings, it was revealed that students need direct instruction and guided support on using visual outlines and learning how they work to enhance reading comprehension before they could internalize the use of this technique for their future readings. It was also indicated that visual outlines facilitate students' text comprehension by organizing the main ideas, which can later be used as a guideline to create their written summaries. In fact, graphic representations enhance reading comprehension and retention through the use of visually illustrated input.

When students notice their improvements, they are motivated to continue using the technique to achieve their learning objectives. After internalizing the technique, they can go on with constructing the graphic illustrations to get a better understanding of their future readings. The ultimate goal of teaching reading is encouraging students to become lifelong, autonomous, and strategic readers.

For further research, other reading strategies and summarization techniques can be tried in both ESP, reading comprehension, and content courses. Further investigation with longer training periods, more extensive reading materials, and learners with different proficiency and learning styles can hopefully widen the horizons of research on reading comprehension enhancement.

\section{References}

Anderson, N. J. (1999). Exploring second language reading: Issues and strategies. Heinle \& Heinle.

Ary, D., Jacobs, L. C., Irvine, C. K. S., \& Walker, D. (2013). Introduction to research in education. Cengage Learning.

Baleghizadeh, S., \& Babapur, M. (2011). The effect of summary writing on reading comprehension and recall of EFL students. New England Reading Association Journal, 47(1), 44-57. https://doi.org/10.5296/jse. v3i2.2644

Biria, R., \& Sharifi, M. M. (2013). Graphic organizers and reading comprehension ability: Evidence from Iranian EFL university students. Sino-US English Teaching, 10(5), 358-365. https://www.researchgate. 
net/publication/259849463_Graphic_Organizers_and_Reading_ Comprehension_Ability_Evidence_from_Iranian_University_ Students

Chang, K. E., Sung, Y. T., \& Chen, I. D. (2002). The effect of concept mapping to enhance text comprehension and summarization. The Journal of Experimental Education, 2002, 71(1), 5-23. https://core.ac.uk/download/pdf/13372428.pdf

Chaury, P. (2015). The effects of strategy instruction on reading comprehension in English as a Foreign Language. Concordia Working Papers in Applied Linguistics, 6, 2-24. https://doe.concordia.ca/copal/documents/1_Chaury_Patrick.pdf

Chmielewski, T., \& Dansereau, D. F. (1998). Enhancing the recall of text: Knowledge mapping training promotes implicit transfer. Journal of Educational Psychology, 90, 407-413. https://doi.org/10.1037/00220663.90.3.407

Ellis, E., \& Howard, P. (2005). Graphic organizers: Power tools for teaching students with learning disabilities. Graphic Organizers and Learning Disabilities, 1, 1-5. https://s3.amazonaws.com/cmi-teaching-ld/ alerts/6/uploaded_files/original_alert13.pdf?0=

Fisher, A. L. (2001). Implementing graphic organizer notebooks: The art and science of content. Reading Teacher, 55(2), 116-120. https://www. jstor.org/stable/20205022

Grabe, W. (2009). Reading in a second language: Moving from theory to practice. Cambridge University Press.

Grabe, W., \& Stoller, L., F. (2011). Teaching and researching reading. Routledge.

Grabe, W., \& Zhang, C. (2013). Second language reading-writing relations. In A. S. Horning \& E. W. Kreamer (Eds.), Reconnecting reading and writing (pp. 108-133). Parlor Press and WAC Clearinghouse.

Graney, M. J. (1992). A framework for using text graphing. System, 20, 161167. https://doi.org/10.1016/0346-251X(92)90022-U

Harris, T., \& Hodges, R. (1995). The literacy dictionary: The vocabulary of reading and writing. International Reading Association.

Hibbard, K. M., \& Wagner, E. A. (2003). Assessing and teaching reading comprehension and writing, $\mathrm{K}-3$. Eye on Education.

Hirvela, A. (2016). Connecting reading and writing in second language writing instruction. University of Michigan. 
Hodaeian, M. \& Biria, R. (2015). The effect of backward design on intermediate EFL learners' L2 reading comprehension: Focusing on learners' attitudes. Journal of Applied Linguistics and Language Research, 2(7), 80-93. https://www.jallr.com/index.php/JALLR/article/view/162/0

Jiang, X., \& Grabe, W. (2007). Graphic organizers in reading instruction: Research findings and issues. Reading in a Foreign Language, 19, 34-55. http://nflrc.hawaii.edu/rfl/April2007/jiang/jiang.pdf

Kamil, M. L. (2004). Vocabulary and comprehension instruction: Summary and implications of the national reading panel findings. Academic Exchange Quarterly, 12, 113-122.

Kiewra, K. A., Kauffman, D. F., Robinson, D. H., Dubois, N. F., \& Stanley, R. K. (1999). Supplementing floundering text with adjunct displays. Instructional Science, 27, 373-401. https://doi.org/10.1023/A:1003270723360

Lee, Y., Baylor, A. L., \& Nelson, D. (2005). Supporting problem solving performance through the construction of knowledge maps. Journal of Interactive Learning Research, 16(2), 117-131. https://eric.ed.gov /?id=EJ726309

Lin, H. Y., \& Chern, L. C. (2014). The effects of background knowledge and L2 reading proficiency on Taiwanese university students' summarization performance. Contemporary Educational Research Quarterly, 22(4), 149-186. https://doi.org/10.6151/CERQ.2014.2204.04

Mall Amiri, B., \& Sarlak, H. (2010). The comparative effect of summarizing and concept mapping on ESP learners' reading comprehension of EAP texts.JELS, 1(4), 113-136. http://journals.iau.ir/article_510808_8fbc8fb0aa141d0381014c2326bb8b7a.pdf

Manoli, P., \& Papadopoulou, M. (2012). Graphic organizers as a reading strategy: Research findings and issues. Creative Education, 3(3), 348356. https://doi.org/10.4236/ce.2012.33055

McKnight, K. (2010). The teacher's big book of graphic organizers. Jossey-Bass.

Mohammad Hoseinpur, R. (2015). The impact of teaching summarizing on EFL learners' microgenetic development of summary writing. The Journal of Teaching Language Skills (JTLS), 7(2), 69-92. https://doi. org/10.22099/jtls.2015.3531

Naseri, H., Asadi, N., \& Zoughi, M. (2013). The effect of teaching systemic-oriented summarization strategies on the reading comprehension of advanced Iranian EFL learners. International Journal of Language Learning and Applied Linguistics word (IJLLALW), 4(4), 74-87. 
National Reading Panel. (2000). Report of the national reading panel: An evidence-based assessment of the scientific research literature on reading and its implications for reading instruction. National Institute of Child Health and Human Development, National Institutes of Health.

O’Donnell, M. P., \& Wood, M. (2004). Becoming a reader: A developmental approach to reading instruction ( $3^{\text {rd }}$ Ed.). Pearson Education.

Pakzadian, M., \& Eslami Rasekh, A. (2012). The effects of using summarization strategies on Iranian EFL learners' reading comprehension. English Language Research, 1(1), 118-125. https://doi.org/10.5430/elr. v1n1p118

Palmer, J. C. (2003). Summarizing techniques in the English language classroom: An international perspective. PASAA, 34, 54-63. https://fs.libarts.psu.ac.th/research/conference/proceedings-3/3pdf/004.pdf

Parker, C. (2007). 30 Graphic organizers for reading. Shell Education.

Pearson, R. S., \& Denner, P. R. (1989). Semantic organizers: A study for special needs learners. Aspen.

Praveen, S. D., \& Premalatha, R. (2013). Using graphic organizers to improve reading comprehension skills for the middle school ESL students. English Language Teaching, 6(2), 155-170. https://doi.org/10.5539/elt. v6n2p155

Robson, C. (1993). Real world research: A resource for social scientist and Practitioner researcher. Blackwell.

Salehi, D. A., Jahandar, S., \& Khodabandehlou, M. (2013). The impact of concept mapping on EFL students. Indian Journal of Fundamental and Applied Life Sciences, 3(3), 241-280. https://www.cibtech.org/J-LIFESCIENCES/PUBLICATIONS/2013/Vol_3_No_3/JLS-32-37...the...comprehension.pdf

Schwartz, S. H., \& Fattaleh, D. L. (1972). Representation in deductive problem solving: The matrix. Journal of Experimental Psychology, 95, 343348. https://doi.org/10.1037/h0033669

Sotiriou, E. P. (2002). Reading to write: Composition in context. Heinle \& Heinle.

Tarshaei, G., \& Karbalaei, A. (2015). The effect of three phase approach on Iranian EFL learners' reading comprehension. European Online Journal of Natural and Social Sciences, 4(2), 362-372. https://european-science. com/eojnss/article/view/2592

van Merrienboer, J. J. G. (1990). Strategies for programming instruction in high school: Program completion vs. program generation. Journal of 
Educational Computing Research, 6, 265-287. https://www.researchgate.net/publication/312990037_Strategies_for_programming_ instruction_in_high_school_Program_completion_vs_Program_ generation

Wallace, R., Pearman, C., Hail, C., \& Hurst, B. (2007). Writing for comprehension. Reading Horizons, 48(1), 41-56. https://scholarworks.wmich. edu/reading_horizons/vol48/iss1/5/

Wormeli, R. (2005). Summerization in any subject: 50 techniques to improve student reading. The Association for Supervision and Curriculum Design (ASCD).

Zafarani, P. \& Kabgani, S. (2014). Summarization strategy training and reading comprehension of Iranian ESP learners. Social and Behavioral Sciences, 98, 1959-1965. https://doi.org/10.1016/j.sbspro.2014.03.629

Zahedi, Z., \& Tabatabaei, O. (2015). The effect of blended teaching on reading strategy use by Iranian EFL learners. International Journal of Foreign Language Teaching \& Research, 3(11), 25-38. https://jfl.iaun.ac.ir/ article_559296.html

Zhao, R., \& Hirvela, A. (2015). Undergraduate ESL students' engagement in academic reading and writing in learning to write a synthesis paper. Reading in a Foreign Language, 27(2), 219-241. https://files.eric.ed.gov/ fulltext/EJ1078373.pdf 